\title{
Foraging activity and submesoscale habitat use of waved albatrosses Phoebastria irrorata during chick-brooding period
}

\author{
Jill A. Awkerman ${ }^{1, *}$, Akira Fukuda ${ }^{2}$, Hiroyoshi Higuchi ${ }^{3}$, David J. Anderson ${ }^{1}$ \\ ${ }^{1}$ Department of Biology, Wake Forest University, Winston-Salem North Carolina 27109-7325, USA \\ ${ }^{2}$ Department of Electrical Engineering, Shizuoka University, Hamamatsu 432-8561, Japan \\ ${ }^{3}$ School of Agriculture and Life Sciences, University of Tokyo, Yayoi 1-1-1, Bunkyo-ku, Tokyo 113-8657, Japan
}

\begin{abstract}
Highly accurate GPS dataloggers, immersion monitors, and remote-sensing images were used to examine the foraging habitat of the waved albatross Phoebastria irrorata with greater resolution than that in previous mesoscale studies, which identified features of foraging trip destinations. Analyses revealed reduced variability in habitat use at finer scales. Bathymetry was consistently a statistically significant predictor of the foraging habitat of parent albatrosses tracked during the 2003 chick-brooding period, when they made short trips close to breeding grounds. These broodstage parents were more active during the day than the night, and nocturnal flight activity was positively correlated with moon phase. All tracked parents travelled to the shallow ( $<600 \mathrm{~m})$ quadrant NNW of the breeding colony on Isla Española, Galápagos. Corroborating the result of a previous study, $92 \%$ of all activity occurred within $100 \mathrm{~km}$ of the breeding colony. Foraging activity was similar for males and females. These data provide critical information on habitat use of the breeding component of the waved albatross population within the newly created Galápagos Marine Reserve.
\end{abstract}

KEY WORDS: Phoebastria irrorata · Galápagos Islands · Seabird habitat

\section{INTRODUCTION}

Oceanographic features that tend to correspond with albatross foraging behavior include frontal zones, bathymetric relief, sea-surface temperature (SST), chlorophyll level, sea surface height, and wind direction. Satellite tracking has shown that albatrosses frequent shelf upwellings, seamount eddies and frontal zones where movements of water masses concentrate prey items at the surface, enabling albatrosses to feed most effectively (Rodhouse et al. 1996, Grémillet et al. 2000, Fernández et al. 2001, Nel et al. 2001, Croxall \& Wood 2002, Hyrenbach et al. 2002, Waugh et al. 2002). Temporal and spatial variability in SST affects prey distribution and consequently seabird breeding success (Schreiber \& Schreiber 1984, Anderson 1989, Inchausti et al. 2003), and steep gradients in chlorophyll level may indicate frontal location and associated high prey availability. Such variability in the marine environment often determines the foraging destinations of albatrosses (Waugh et al. 2002).

While habitat use has been studied at the mesoscale, addressing behavioral responses to oceanographic variability on the scale of $10 \mathrm{~s}$ to $100 \mathrm{~s}$ of $\mathrm{km}$, studies at a finer spatial and temporal scale have awaited the application of miniaturized Global Positioning System technology, which is now available and used to track freeranging albatrosses (Weimerskirch et al. 2002, Fukuda et al. 2004). Locations from GPS dataloggers have low error and, potentially, a higher rate of data acquisition, without requiring extrapolation based on infrequent fixes. With GPS data we can test hypotheses regarding oceanographic predictors of fine-scale habitat patch use, integrating satellite-based remote-sensing images of oceanic habitat with GPS-acquired movement data and other behavioral data from immersion monitors.

A submesoscale $(<10 \mathrm{~km})$ approach is needed to study albatross habitat use during the chick-brooding 
period, when small hatchlings require parental attendance and frequent meal deliveries, and albatross parents, as central place foragers, contract their foraging ranges to the area within 10s or 100s of kilometers of the breeding site (Berrow \& Croxall 2001, Fernández et al. 2001, Shaffer et al. 2003). Pelagic seabirds dependent on patchy distribution of prey resources, such as wandering albatrosses and cape gannets, demonstrate scale-dependent movement in response to patchy distribution of resources in a heterogeneous pelagic environment (Fritz et al. 2003, Grémillet et al. 2004).

During incubation and chick-rearing, especially when chicks no longer require parental attendance, many albatross species travel thousands of kilometers to continental shelves, foraging in zones that differ in depth, SST and productivity from waters closer to the breeding grounds. Notable among these are the Phoebastria species, inhabiting the central and north Pacific (Anderson et al. 1998, 2003, Fernández et al. 2001, Hyrenbach et al. 2002). In the case of the waved albatross $P$. irrorata nesting on the Galápagos Islands, breeding adults travelled to the shallow, cool, nutrientrich Peruvian upwelling during incubation and chickrearing (Anderson et al. 1998, Fernández et al. 2001); during chick-brooding they make short trips within the Galápagos Marine Reserve (GMR; the area within the archipelago, plus a 40 nautical mile buffer zone; Anderson et al. 2003). Our study tests the hypothesis that waved albatrosses occupy similar habitat patches during chick-brooding, when their limited foraging range raises the importance of submesoscale oceanographic variation.

Waved albatrosses nest almost exclusively at 1 site in the Galápagos Islands in the eastern tropical Pacific (Anderson et al. 2002), where the convergence of several currents over an area with significant bathymetric relief creates an heterogeneous marine environment. Currents enter the archipelago from the NE (Panama Current), SE (Humboldt Current), and W (Cromwell Current), and 2 countercurrents to the north of the archipelago create an equatorial front (Spear et al. 2001). Most notably, the subsurface Cromwell Current, flowing in an easterly direction across an area of rapidly changing bathymetry, creates a rich and productive upwelling area on the west side of the archipelago supporting populations of seabirds and several other marine predator species. Near the waved albatross breeding colony on Isla Española, at the southeastern edge of the archipelago, bathymetry varies greatly and several seamounts located to the northwest of Isla Española within a shallow inter-island area (Houvenaghel 1984) attract aggregations of boobies and cetaceans (Anderson \& Ricklefs 1987). While aggregations of waved albatrosses of unknown breeding status (possibly brood-stage birds) are observed over the upwelling in the western archipelago (Merlen 1996), satellite tracking data indicate that brooding-stage breeders tend to forage in the SE quadrant of the archipelago (Anderson et al. 2003) in relatively less productive waters.

Characteristic features associated with foraging habitat of other low latitude albatross species are cooler temperatures, high productivity and shallower bathymetry. In the Hawaiian Islands, rearing-stage Laysan Phoebastria immutabilis and black-footed P. nigripes albatrosses make long trips to productive upwellings over continental shelves (Fernández et al. 2001, Hyrenbach et al. 2002). However, during the brooding stage when trip-range is restricted (Fernández et al. 2001), both species make short trips to pelagic, oligotrophic, tropical waters, frequenting water that is deeper, warmer, and less-productive than the foraging areas accessed during the rearing period. It is unknown whether brood-stage albatrosses in Hawaii occupy cooler, more productive patches within their restricted foraging area or if the smaller area is relatively homogeneous with regard to oceanographic variables.

The timing and method of prey capture by waved albatrosses is not well-documented. However, scavenging behavior and a tendency to feed in large, frenetic aggregations was observed by Merlen (1996). The bulk of the waved albatross diet was reported to consist of squid and fishes by Harris (1973), who found pelagic crustaceans (euphasiids, krill and isopods) in half of his samples. Weimerskirch \& Wilson (1992) found that the wandering albatross Diomedea exulans ingested squid and other prey items mostly during daylight hours, and prey capture usually occurred immediately following landing on the water (Weimerskirch et al. 1997c). However, nocturnal prey capture has also been recorded in this and other albatross species (Weimerskirch et al. 1994). Because several of the squid species consumed by albatrosses are bioluminescent and because tropical squid and small fishes approach the sea surface at night (Spear et al. 2001), albatrosses might be expected to forage actively, or even primarily, at night, especially species such as the Laysan albatross Phoebastria immutabilis, which has unusually high concentrations of rhodopsin in its eyes (Harrison et al. 1983). However, Laysan and blackfooted albatrosses are more active during daylight hours (Fernández \& Anderson 2000).

In this paper we identify fine scale heterogeneity in the foraging habitat of waved albatrosses during the brooding period and focus on differences in foraging behavior associated with habitat, sex and the diel cycle. We test the hypotheses that waved albatross foraging activity is non-random with respect to variation in submesoscale oceanographic variables, and that foraging activity is non-random with respect to time of day. Identification of 
the core foraging habitat of waved albatrosses within the GMR is required for effective protection of this species from becoming a bycatch of long-line fisheries, which are often active in the same areas that albatrosses favor (Anderson et al. 1998, Prince et al. 1998, Grémillet et al. 2000, Inchausti \& Weimerskirch 2001, 2002, Jahncke et al. 2001). Long-line bycatch has been linked to population declines of several other albatross species (Weimerskirch \& Jouventin 1987, Croxall et al. 1990, Brothers 1991, Weimerskirch et al. 1997a, Inchausti \& Weimerskirch 2001), and both legal pilot programs and illegal industrial long-liners have operated recently within the GMR.

\section{MATERIALS AND METHODS}

Data acquisition. We studied waved albatrosses nesting at Punta Cevallos $\left(1^{\circ} 23^{\prime} \mathrm{S}, 89^{\circ} 37^{\prime} \mathrm{W}\right)$, the SE point of Isla Española, during $4 \mathrm{wk}$ of the chickbrooding period (29 June to 26 July) of the 2003 breeding season. Most (90\%) eggs were laid between 16 April and 19 May, and hatching began on 24 June. We attached GPS units (66 g; Fukuda et al. 2004) to dorsal feathers with Tesa ${ }^{\circledR}$ tape, and immersion monitors (5 g; Model IMV2, Ferguson Manufacturing) to metal leg bands with plastic cable ties. The mass of equipment was approximately 1.5 to $2 \%$ of the adult body mass. We observed nests until a brood-shift change occurred, and then deployed the equipment on the departing bird. The programmable GPS units recorded location every $60 \mathrm{~min}$, and immersion monitors recorded durations of immersions and emersions with $1 \mathrm{~s}$ precision. Of the 21 birds tagged, 5 provided data from 2 trips, resulting in 13 trips from males and 13 from females. Second trips were considered independent of the preceding trip, since successive trips from the same bird overlapped little in trip direction or destination, and since variance in total distance and duration of trip was comparable to that of randomly paired trips from the remaining tracks.

Prior to the first deployment, all GPS units were placed $10 \mathrm{~m}$ apart on the ground at Punta Cevallos for ground-truthing. Locations of these stationary units were recorded at $30 \mathrm{~min}$ intervals for $24 \mathrm{~h}$ and the recorded data were compared to those measured by a commercial GPS unit (GPS 12, Garmin International).

A subset of the nests (33) in our study area were checked every $3 \mathrm{~h}$ throughout the brooding period to record parent attendance at the nest or their presence in the vicinity. These data were used to estimate trip durations of untagged birds, to assess the potential effects of handling and equipment on tagged parents.

Data for SST at $4 \mathrm{~km}$ resolution from the MODIS Aqua satellite were obtained from NASA's Physical
Oceanography Distributed Active Archive Center of the Jet Propulsion Laboratory (available at: http:// podaac-esip.jpl.nasa.gov). Chlorophyll data collected by the MODIS Aqua satellite at $4 \mathrm{~km}$ resolution were obtained from SeaWiFS through NASA Goddard Space Flight Center (GSFC) Distributed Active Archive Center (DAAC). Cloud cover over the foraging area resulted in incomplete daily satellite images of SST and chlorophyll. Thus, we used $8 \mathrm{~d}$ composites to assign SST and chlorophyll values to trips. For the submesoscale approach of the habitat analyses, the $4 \mathrm{~km}$ composite data gave fine-resolution composite images of a small area for which daily images were often incomplete. High-resolution data for wind direction and sea-height anomaly were not available for the inter-island area visited by the birds. Ocean depth was determined from the General Bathymetric 1 min Chart of the Oceans (GEBCO, available at: http://www. ngdc.noaa.gov/mgg/gebco/grid/1mingrid.html).

Data analysis. GPS and immersion-monitor data were examined to identify associations of albatross activity with solar and lunar cycles and oceanographic variables, as well as any sex differences in activity or habitat preference. We used the 'animal movement' extension of the ArcView Geographic Information System (Version 3.2; Environmental Systems Research Institute) to construct flight paths and calculate kernel densities from GPS locations. Distances between locations and distances of locations from the colony were determined using the 'great circle' formula (Fitzpatrick \& Modlin 1986). The 'path with distance and bearings' ArcView extension (Jenness Enterprises; available at http://www.jennessent.com/arcview/arcview_extensions. htm) was used to determine turning angle (the absolute value of the angle formed by a given GPS location and the previous and subsequent locations). We also calculated straight-line groundspeed as the distance between 2 consecutive GPS locations divided by the time difference between the locations.

To categorize GPS locations according to behavior, we made the assumption that the turning angle is greater and the flight speed lower during foraging than when traveling in search of prey, since a bird in a food patch should remain in the same area (Anderson et al. 1998, Nel et al. 2001, Hyrenbach et al. 2002). Some of our tracks included a series of GPS locations showing slow movement on a constant bearing, typically at night (see Fig. 8), consistent with a third type of movement: floating with the current and probably resting rather than foraging. Frequency distributions of turning angle and speed suggested discontinuities in movement patterns associated with speeds greater than $4 \mathrm{~km} \mathrm{~h}^{-1}$ (Fig. 1) and turning angles greater than $18^{\circ}$ (Fig. 2). We categorized all GPS locations associated with a speed $>4 \mathrm{~km} \mathrm{~h}^{-1}$ to the next location as 


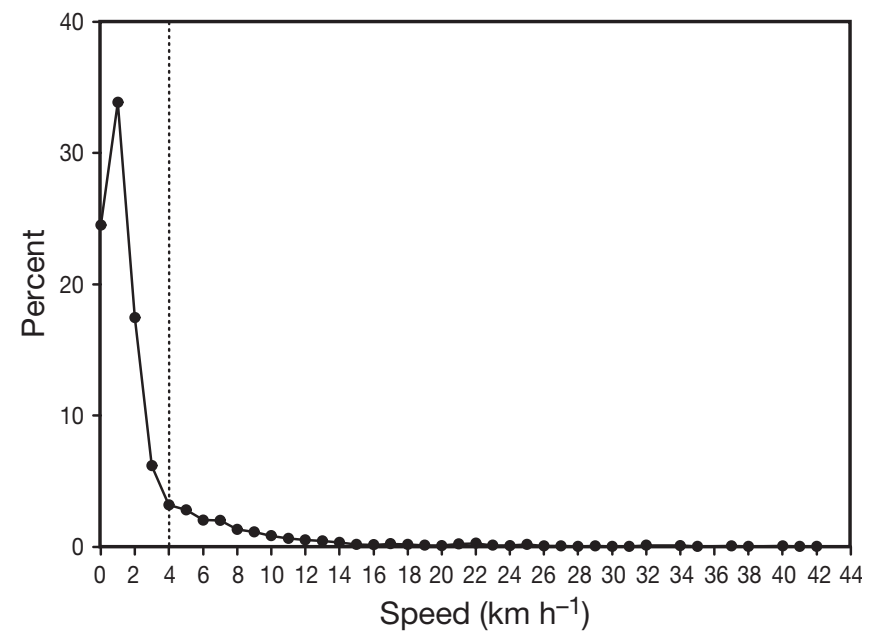

Fig. 1. Phoebastria irrorata. Frequency distribution of speed between consecutive GPS locations

travelling. GPS locations associated with speeds $\leq 4 \mathrm{~km}$ $\mathrm{h}^{-1}$ and a turning angle $\leq 18^{\circ}$ were considered to indicate floating, and GPS locations associated with speeds $\leq 4 \mathrm{~km} \mathrm{~h}^{-1}$ and a turning angle $>18^{\circ}$ were considered to indicate foraging. Because immersion monitor data were not obtained for all of the 26 trips, these data were not included in our definition of behavior. GPS locations recorded between the hours of 06:00 and 18:30 were considered diurnal, and all other activity was considered nocturnal, corresponding to the times of local civil twilight.

Habitat use was examined at 3 spatial scales. For a 'general habitat' analysis, we overlaid a circle centered on Punta Cevallos, with a radius equal to the maximum distance travelled from Punta Cevallos by any tracked bird during the brooding period (165 km), representing the entire region within which tagged birds could have foraged (Fig. 3). Within that circle, we established an orthogonal grid with intersections ('grid points') at 1.85 $\mathrm{km}$ intervals (determined by the resolution of the bathymetry data). At each of the 25007 grid points within the circle, we examined weekly means of 3 oceanographic parameters (depth, SST, chlorophyll) from remote-sensing images. We then identified 4 weekly foraging-range polygons that encompassed all GPS locations for that week, and considered all grid points within a weekly foraging range polygon as 'visited'. Points within the circle but out-

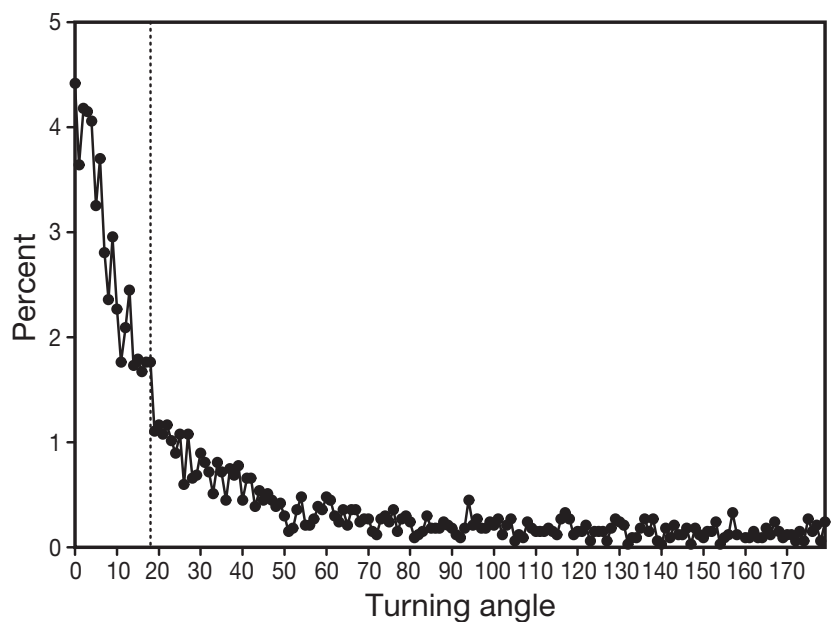

Fig. 2. Phoebastria irrorata. Frequency distribution of turning angle in degrees of 3 sequential GPS locations

side the weekly polygon were 'unvisited', and points within an exclusion zone near the colony were omitted from the analysis (see next paragraph). In the general habitat analysis, we used discriminant function analysis (DFA) to evaluate the ability of SST, chlorophyll concentration and bathymetry to differentiate visited and unvisited grid points. We conducted this analysis

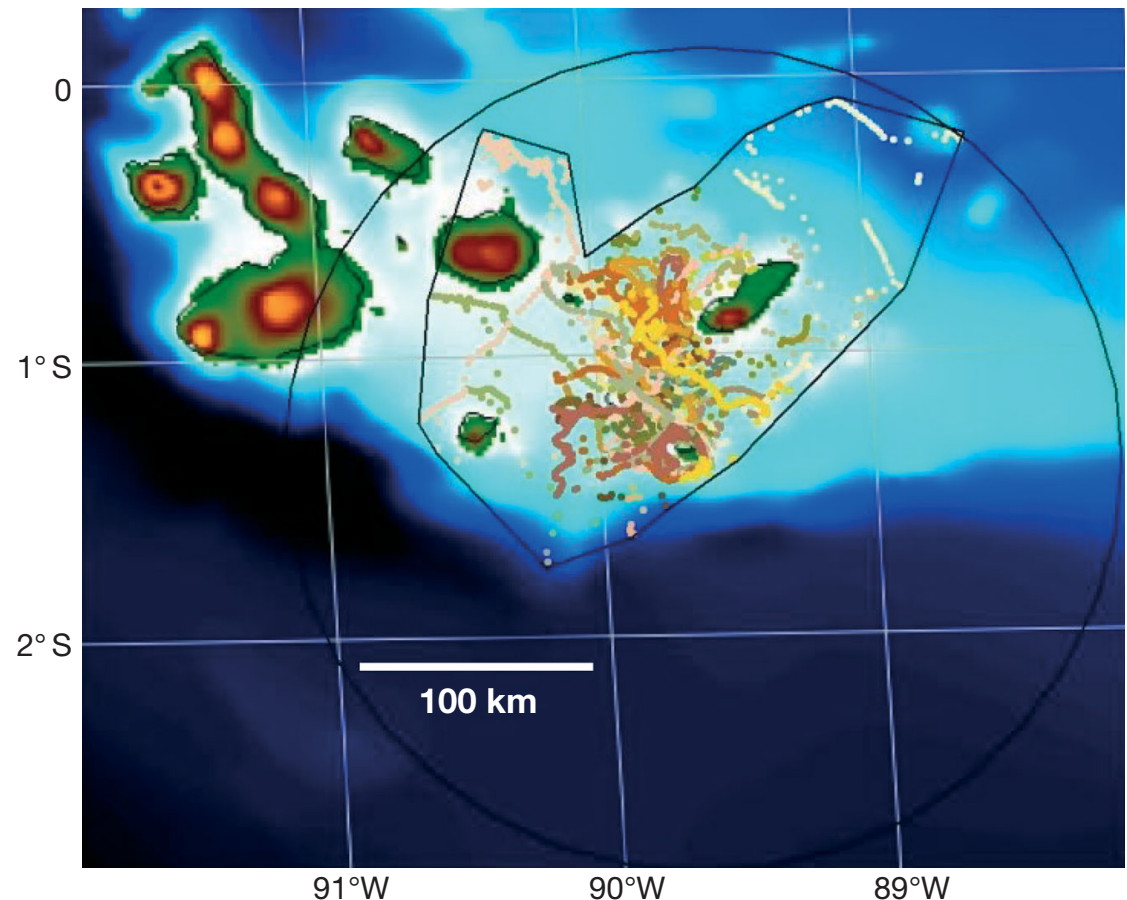

Fig. 3. Phoebastria irrorata. GPS locations for 26 trips of brood-stage waved albatrosses. Circle with radius of $165 \mathrm{~km}$ encloses entire region within which tagged birds could have foraged, as used in general habitat analysis; polygon encloses 'visited' areas, as used in within foraging range analysis (see second subsection of 'Materials and methods'). Dark blue indicates deeper water; light blue/white indicates coastal waters $(<600 \mathrm{~m})$; other area shading indicates terrestrial topography 
on a weekly basis, spatially joining georeferenced layers of habitat data with ArcView.

In a second approach restricted to the visited area, we analyzed data within the entire foraging range polygon (encompassing all GPS locations from all weeks; Fig. 3), computing weekly kernel density of GPS locations classified as foraging within this polygon. We then used multiple regression to detect any relationships between the weekly foraging, kernel-density value and the weekly means of oceanographic parameters that had been linked with a spatial join of georeferenced layers. GPS locations in the immediate vicinity (within $10 \mathrm{~km}$ ) of the colony were excluded, based on an a priori expectation that birds would congregate in large non-foraging rafting aggregations within several kilometers of shore (Harris 1973, J. A. Awkerman \& D. J. Andersen pers. obs.), and because foraging breeders had no choice but to pass through this area going to and from their nests. Excluded GPS locations comprised a core concentration of all GPS locations in an initial kernel-density analysis and represented $14.1 \%$ of all GPS locations, and their exclusion enhanced the resolution of the kernel analysis. Most (64.3\%) of the eliminated GPS locations had been classified as foraging locations based on angle and speed, $24.3 \%$ were floating locations, and $11.4 \%$ were travelling locations. The eliminated GPS locations represented $7.6 \%$ of all floating locations, $9.0 \%$ of all travelling locations, and $24.7 \%$ of all foraging locations. The high density of GPS locations near the colony, and the high proportion of foraging locations, gave an incorrect indication that this area was a preferred foraging habitat, justifying the exclusion of this zone in analyses of habitat-use or behavior.

Finally, we performed an analysis restricted to the GPS tracks themselves, using oceanographic and bathymetric data at each GPS location as determined by spatially joining georeferenced layers of data. We then categorized the bird's behavior at each GPS location as floating, traveling or foraging, and used a DFA of habitat variables, sex, week and hour of day to identify any predictors of behavior. Missing values in remotesensing data for SST and chlorophyll (representing $5.1 \%$ of the total SST values and $5.9 \%$ of total chlorophyll values) were replaced with nearest known values along the track of the bird.

Analyses of general trip characteristics, such as duration, include the entire track, but analyses addressing habitat use or behavior on foraging trips exclude the rafting zone through which birds moved. Statistical tests were performed with Statistica (Version 5.5 and 6.0; Statsoft 1999). Parametric statistical tests were used when required assumptions were met. Statistical significance was set at $\alpha=0.05$. Data on proportions were not adjusted using the arcsine transformation, based on the recommendation by Zar (1996).

\section{RESULTS}

The average deviation of stationary GPS units from the commercial GPS unit during ground-truthing was $4.6 \mathrm{~m}(\mathrm{SD}=2.8 \mathrm{~m}$, median $=3.9 \mathrm{~m}$, range $=0.0$ to $18.9 \mathrm{~m})$. While deployed on birds, the GPS units acquired $96.4 \%(\mathrm{SD}=3.6 \%$, range $=83$ to $100 \%)$ of the scheduled locations. Of the immersion monitors, 14 yielded data, while the remaining 7 were damaged by leakage or failed to download their data. Thus, immersion data are available for only 14 of the 26 trips.

\section{General characteristics of complete trip}

Trips of tagged birds lasted 19 to $273 \mathrm{~h}$ (mean $=99.4$, $\mathrm{SD}=58.6 \mathrm{~h}$, median $=92.5 \mathrm{~h}$ ) and total trip distance was 65 to $650 \mathrm{~km}$ (mean $=299.3 \mathrm{~km}, \mathrm{SD}=147.8 \mathrm{~km}$, median $=$ $274.1 \mathrm{~km}$ ). The average duration of 241 trips of 33 pairs of non-tagged parents during the brooding stage was significantly shorter $(51.9 \mathrm{~h}$; Student's $t$-test, $t=5.45, \mathrm{df}=$ $303, \mathrm{p}<0.005)$. However, the range for tagged birds was similar to that of non-tagged birds (6 to $261 \mathrm{~h}$ ), and $96.2 \%$ of the trips of tagged birds fell within the range of trip lengths of untagged birds. Of the 31 families with a tagged parent, 9 (29.0\%) fledged a chick compared with 45 of 142 families $(31.7 \%)$ without a tagged parent in the rest of the breeding colony ( $G$-test $=0.09$, $\mathrm{df}=1, \mathrm{p}>0.75)$.

The age of the foraging adult's chick was not significantly correlated with the trip's total distance (Spearman rank correlation $r=0.30, n=26, p=0.14)$, its duration $(r=$ $0.01, \mathrm{n}=26, \mathrm{p}=0.99)$, or the bird's average speed $(\mathrm{r}=$ $0.35, \mathrm{n}=26, \mathrm{p}=0.08$ ). We divided each trip (including time spent in the exclusion zone) of tagged birds into 5 segments of equal duration and found no difference in average speed per segment (ANOVA, $F_{1,4}=0.224, \mathrm{p}=$ 0.92 ) indicating that trips had no distinct commuting and foraging portions on that time scale.

None of the albatrosses travelled to pelagic waters (>3000 m) during brooding (Fig. 3). All of the tracks remained within the archipelago over the relatively shallow Galápagos Platform, in the quadrant NW of Española. None of the birds approached the shelf-break south of the island or the productive upwelling in the western archipelago. The majority of the GPS locations (92\%) were over depths $<600 \mathrm{~m}$. We calculated the mean depth of the locations for each of the 26 trips: the mean of these 26 means was $391 \pm 193 \mathrm{~m}$ (median $=340 \mathrm{~m})$.

\section{General habitat analysis}

The 4 discriminant function analyses comparing bathymetry and weekly oceanographic variables at visited and non-visited grid points (inside and outside 
weekly foraging polygons, respectively) showed significant effects of the habitat variables on habitat-use in each of the 4 wk (Week 1: Wilks' $\lambda=0.92, F_{3,23236}=$ 705.3, p < 10 ${ }^{-4}$; Week 2: Wilks' $\lambda=0.80$, $F_{3,22502}=1927.7, \mathrm{p}<10^{-4}$; Week 3: Wilks' $\lambda=0.81, F_{3,22626}=1773.6, \mathrm{p}<10^{-4}$; Week 4: Wilks' $\lambda=0.93, F_{3,22100}=588.5, \mathrm{p}<10^{-4}$ ). Bathymetry had a significant effect in all $4 \mathrm{wk}$, reflecting the movement of birds over the Galápagos Platform and not over pelagic waters (Table 1). Chlorophyll concentration also showed a significant effect in all $4 \mathrm{wk}$, as did SST in Weeks 2 to 4 (Table 1). The ability of the habitat variables to predicted habitat-use was highest for bathymetry (mean $\left.r^{2}=0.139\right)$; those of SST and chlorophyll concentration were lower (mean $\mathrm{r}^{2}=0.059$ and 0.09, respectively). Areas visited were generally shallower, cooler, and more productive than were the unvisited areas within the maximum distance traveled (Table 1).

\section{Within foraging range analysis}

Kernel analysis (omitting data from the exclusion zone) identified 2 areas within the entire foraging-range polygon with high densities of GPS locations, both within several kilometers of the seamount Banco Ruso (Fig. 4). Multiple regression of kernel density of GPS locations classified as foraging on bathymetry, SST and chlorophyll concentration was significant for each of the $4 \mathrm{wk}$ (Week 1: $F_{3,5791}=$ 217.62, $\mathrm{p}<10^{-4}$; Week 2: $F_{3,5589}=263.93, \mathrm{p}$ $<10^{-4}$; Week 3: $F_{3,5700}=331.88, \mathrm{p}<10^{-4}$; Week 4: $F_{3,5273}=72.99, \mathrm{p}<10^{-4}$ ). Bathymetry showed a significant negative correlation with kernel density in all $4 \mathrm{wk}$, indicating that behavior classified as foraging occurred in shallower parts of the weekly foraging-range polygon (Table 2). SST and chlorophyll concentration showed both negative and positive correlations with kernel density (Table 2).
Table 1. Phoebastria irrorata. Discriminant function analyses of general habitat use [bathymetry: $\mathrm{m}_{;}$SST (sea-surface temperature): ${ }^{\circ} \mathrm{C}_{i}$ chlorophyll: $\mathrm{mg} \mathrm{m}^{-3}$ ] for each of the 4 wk of the study, using each week's foraging range polygon to identify gridpoints as visited or unvisited (see 'Materials and methods'). Habitat data from land masses and rafting exclusion zone near breeding colony were excluded

\begin{tabular}{|lccccc|}
\hline Parameter & Wilks' & p-level & $\mathrm{r}^{2}$ & \multicolumn{2}{c|}{$\begin{array}{c}\text { Mean } \pm \text { SD foraging } \\
\text { outside polygon }\end{array}$} \\
& $\lambda$ & & & within polygon & \\
Week 1 & & & & & \\
Bathymetry & 0.942 & $<10^{-6}$ & 0.22 & $393.8 \pm 142.7$ & $1996.3 \pm 1182.0$ \\
SST & 0.929 & $<10^{-6}$ & 0.14 & $19.5 \pm 0.9$ & $19.9 \pm 1.5$ \\
Chlorophyll & 0.935 & $<10^{-6}$ & 0.13 & $0.33 \pm 0.10$ & $0.25 \pm 0.09$ \\
Week 2 & & & & & \\
Bathymetry & 0.991 & $<10^{-6}$ & 0.07 & $508.4 \pm 502.9$ & $2143.1 \pm 1127.7$ \\
SST & 0.860 & 0.301 & 0.03 & $20.1 \pm 1.9$ & $20.3 \pm 1.9$ \\
Chlorophyll & 0.861 & 0.161 & 0.07 & $0.42 \pm 0.39$ & $0.29 \pm 0.29$ \\
Week 3 & & & & & \\
Bathymetry & 0.894 & $<10^{-6}$ & 0.03 & $393.8 \pm 223.7$ & $2095.8 \pm 1144.6$ \\
SST & 0.808 & $<10^{-6}$ & 0.04 & $18.0 \pm 1.4$ & $19.1 \pm 1.7$ \\
Chlorophyll & 0.769 & $<10^{-6}$ & 0.02 & $0.34 \pm 0.15$ & $0.29 \pm 0.13$ \\
Week 4 & & & & & \\
Bathymetry & 0.968 & $<10^{-6}$ & $<10^{-3}$ & $980.1 \pm 549.3$ & $2024.5 \pm 1203.9$ \\
SST & 0.898 & $<10^{-6}$ & 0.072 & $18.4 \pm 1.7$ & $18.2 \pm 1.8$ \\
Chlorophyll & 0.889 & $<10^{-6}$ & 0.16 & $0.27 \pm 0.10$ & $0.25 \pm 0.16$ \\
\hline
\end{tabular}

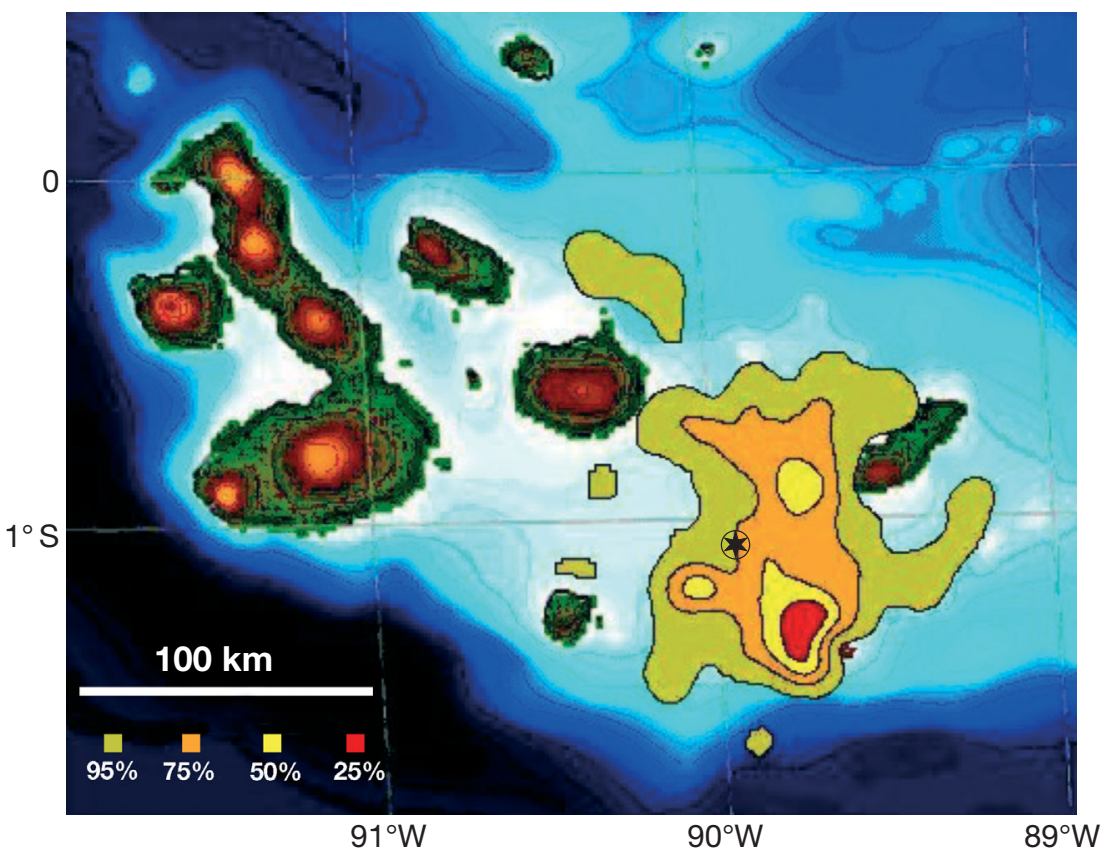

Fig. 4. Phoebastria irrorata. Kernel density of GPS locations $\geq 10 \mathrm{~km}$ from breeding colony. Position of seamount Banco Ruso is indicated by circled star to NW of Isla Española. Proportion of total albatross hours are shown in colour legend

\section{Analysis of habitat and behavior along GPS tracks}

For all locations on GPS tracks outside the exclusion zone, DFA using habitat variables (bathymetry, SST and chlorophyll) to distinguish among behaviors (for- aging, traveling and floating) was significant in 3 of the 4 weeks (Week 1: Wilks' $\lambda=0.966, F_{6,462}=1.35, \mathrm{p}<$ 0.235; Week 2: Wilks' $\lambda=0.991, F_{6,2890}=2.24, \mathrm{p}<0.037$; Week 3: Wilks' $\lambda=0.984, F_{6,1976}=2.74, \mathrm{p}<0.012$; Week 4: Wilks' $\left.\lambda=0.933, F_{6,374}=2.21, \mathrm{p}<0.042\right)$. Floating and foraging usually occurred over shallower 
Table 2. Phoebastria irrorata. Multiple regression of foragingkernel density on oceanographic $\left(\mathrm{SST}:{ }^{\circ} \mathrm{C}\right.$; chlorophyll: $\mu \mathrm{g}$ $\mathrm{m}^{-3}$ ) and bathymetric $(\mathrm{m})$ values for each grid point within overall foraging zone for each of the 4 wk of tracking. Land masses and rafting exclusion zone were excluded

\begin{tabular}{|lrrrc|}
\hline Parameter & Beta & Beta SE & $t$ & p-level \\
\hline Week 1 & & & & \\
Intercept & & & 1.66 & 0.10 \\
Bathymetry & -0.187 & 0.014 & 13.02 & $<10^{-6}$ \\
SST & 0.032 & 0.014 & 2.38 & 0.02 \\
Chlorophyll & 0.207 & 0.013 & 15.48 & $<10^{-6}$ \\
Week 2 & & & & \\
Intercept & & & 24.25 & $<10^{-6}$ \\
Bathymetry & -0.328 & 0.013 & 25.40 & $<10^{-6}$ \\
SST & -0.209 & 0.013 & 16.53 & $<10^{-6}$ \\
Chlorophyll & -0.049 & 0.013 & 3.76 & $<10^{-4}$ \\
Week 3 & & & & \\
Intercept & & & 23.95 & $<10^{-6}$ \\
Bathymetry & -0.230 & 0.013 & 18.06 & $<10^{-6}$ \\
SST & -0.208 & 0.013 & 16.23 & $<10^{-6}$ \\
Chlorophyll & -0.129 & 0.012 & 10.43 & $<10^{-6}$ \\
Week 4 & & & & \\
Intercept & & & 1.06 & 0.14 \\
Bathymetry & -0.102 & 0.014 & 7.77 & $<10^{-6}$ \\
SST & 0.017 & 0.014 & 1.70 & 0.22 \\
Chlorophyll & 0.160 & 0.014 & 11.19 & $<10^{-6}$ \\
\hline
\end{tabular}

waters than did travelling, while the discriminatory ability of SST and chlorophyll varied more by week at this scale (Table 3). Trip-specific DFAs of behavior indicated that for 12 of 25 trips, habitat variables were not significant predictors of behaviors. For 10 of the 25 trips, bathymetry was a significant indicator of behavior ( $\mathrm{p}<0.05)$; for 5 of the trips, chlorophyll was a significant indicator; and for 3 of the trips, SST was a significant predictor.

\section{Comparison of sexes}

The spatial distribution of kernel density indicated that males and females showed similar habitat-use (Fig. 5). Multivariate analysis of variance of 9 trip characteristics (Table 4) indicated no significant difference between male and female trips (Wilks' $\lambda=0.47, \mathrm{df}_{1}=8$, $\left.\mathrm{df}_{2}=7, \mathrm{p}=0.52\right)$.

\section{Cyclic aspects of foraging activity}

Comparing within trips to control inter-individual differences, daytime landings were 4.0 times as frequent as night landings (paired $t$-test, $\mathrm{n}=15, t=3.2$, $\mathrm{p}=0.006$ ) and mean speed during the day was on average 2.92 times that during the night (paired $t$ test, $t=7.75, \mathrm{df}=25, \mathrm{p}<0.005)$. The median duration of continuous periods spent in the water, as indicated by immersion monitors, was distinctly lower when the period began during daylight hours (06:00 to 18:30; Fig. 6; paired t-test, $t=3.9$, df $=14, \mathrm{p}=$ 0.001).

Almost all (95\%) travelling occurred during daylight hours, and $71 \%$ of floating occurred during the night. Most (68\%) GPS locations associated with behavior categorized as foraging occurred during the day. Paired $t$-tests comparing diurnal versus nocturnal behavior of the 26 birds showed significant differences in the proportion of time spent floating (paired $t$-test, $t=16.4, \mathrm{df}=25, \mathrm{p}<0.005$ ), traveling $(t=11.0, \mathrm{df}=25, \mathrm{p}<0.005)$ and foraging $(t=4.4$, $\mathrm{df}=25, \mathrm{p}<0.005)$ with higher frequencies of floating at night and travelling and foraging during the day (Fig. 7).

Table 3. Phoebastria irrorata. Discriminant function analysis of bathymetry $(\mathrm{m}), \mathrm{SST}\left({ }^{\circ} \mathrm{C}\right)$, and chlorophyll concentration $\left(\mathrm{mg} \mathrm{m}^{-3}\right)$ identifying predictors of movement-related behavior (mean \pm SD) beyond $10 \mathrm{~km}$ radius of colony. Missing SST and chlorophyll data were replaced with the nearest known value on the GPS track

\begin{tabular}{|c|c|c|c|c|c|c|}
\hline \multirow{2}{*}{ Parameter } & \multirow{2}{*}{$\begin{array}{c}\text { Wilks' } \\
(\lambda)\end{array}$} & \multirow{2}{*}{ p-level } & \multirow[t]{2}{*}{$\mathrm{r}^{2}$} & \multicolumn{3}{|c|}{ - Behavior - } \\
\hline & & & & Floating & Traveling & Foraging \\
\hline \multicolumn{7}{|l|}{ Week 1} \\
\hline Bathymetry & 0.967 & 0.848 & 0.040 & $374.2 \pm 138.1$ & $385.2 \pm 160.6$ & $376.8 \pm 136.0$ \\
\hline SST & 0.985 & 0.103 & 0.497 & $19.66 \pm 0.86$ & $19.64 \pm 1.09$ & $19.99 \pm 0.85$ \\
\hline Chlorophyll & 0.967 & 0.837 & 0.501 & $0.337 \pm 0.104$ & $0.342 \pm 0.107$ & $0.367 \pm 0.128$ \\
\hline \multicolumn{7}{|l|}{ Week 2} \\
\hline Bathymetry & 0.997 & 0.007 & 0.058 & $394.1 \pm 251.4$ & $440.6 \pm 391.2$ & $453.3 \pm 430.7$ \\
\hline SST & 0.991 & 0.715 & 0.048 & $19.11 \pm 2.15$ & $19.21 \pm 2.15$ & $19.28 \pm 2.23$ \\
\hline Chlorophyll & 0.993 & 0.246 & 0.070 & $0.374 \pm 0.262$ & $0.403 \pm 0.363$ & $0.379 \pm 0.272$ \\
\hline \multicolumn{7}{|l|}{ Week 3} \\
\hline Bathymetry & 0.990 & 0.041 & 0.034 & $353.7 \pm 151.6$ & $386.2 \pm 189.4$ & $383.6 \pm 185.9$ \\
\hline SST & 0.991 & 0.024 & 0.026 & $17.61 \pm 1.23$ & $17.60 \pm 1.16$ & $17.84 \pm 1.20$ \\
\hline Chlorophyll & 0.985 & 0.612 & 0.037 & $0.299 \pm 0.078$ & $0.308 \pm 0.094$ & $0.306 \pm 0.101$ \\
\hline \multicolumn{7}{|l|}{ Week 4} \\
\hline Bathymetry & 0.948 & 0.215 & 0.082 & $768.4 \pm 517.7$ & $838.9 \pm 513.5$ & $664.8 \pm 417.8$ \\
\hline SST & 0.943 & 0.360 & 0.152 & $17.57 \pm 1.07$ & $17.96 \pm 1.74$ & $17.73 \pm 1.37$ \\
\hline Chlorophyll & 0.969 & 0.029 & 0.079 & $0.289 \pm 0.103$ & $0.289 \pm 0.197$ & $0.369 \pm 0.269$ \\
\hline
\end{tabular}




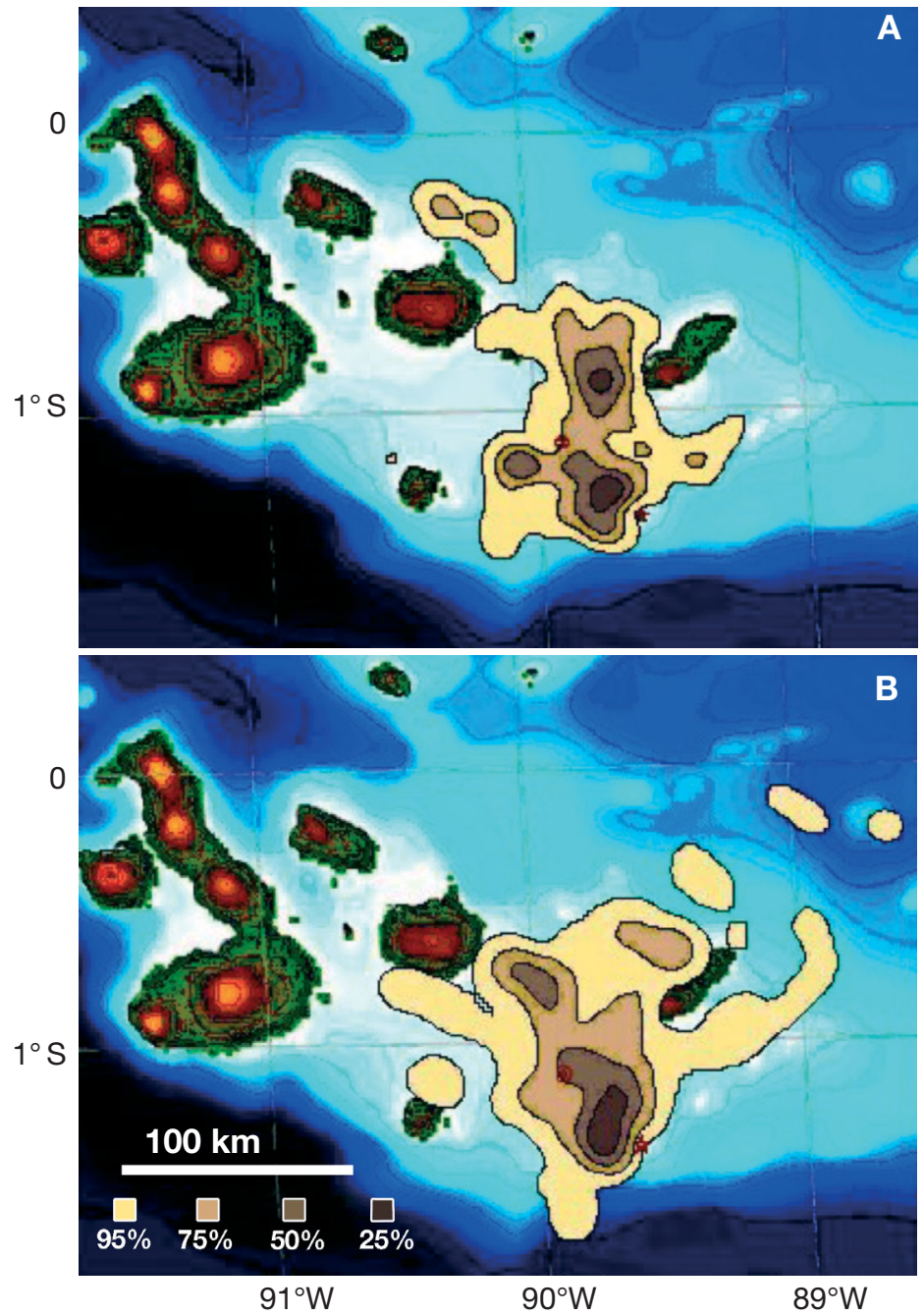

Fig. 5. Phoebastria irrorata. Kernel density of GPS locations of (A) males and (B) females $\geq 10 \mathrm{~km}$ from breeding colony. Proportion of total albatross hours are shown in colour legend

Males landed 6.4 times more frequently during the day than the night (paired $t$-test, $t=3.2$, df $=7, \mathrm{p}=$ 0.018 ), and females landed 3.5 times more frequently during the day than the night (paired $t$-test, $t=4.1$, $\mathrm{df}=5, \mathrm{p}=0.015)$. For several trips the nocturnal GPS locations were a series of equidistant points in a straight line, suggesting that a bird landed on the water at dusk and floated with the current until dawn (Fig. 8). Categorizing nocturnal locations according to the 3 movement-defined behaviors, lunar phase was positively correlated with proportion of nocturnal travelling behavior (Spearman rank correlation $r=0.72$, $\mathrm{n}=14, \mathrm{p}<0.005)$, but not with proportion of nocturnal floating ( $\mathrm{r}=-0.30, \mathrm{n}=14, \mathrm{p}=0.30$ ) or proportion of nocturnal foraging activity $(\mathrm{r}=0.24, \mathrm{n}=14, \mathrm{p}=0.42)$, when nights were coded 0 to 14 in accordance with proximity to new (0) and full (14) moon.

\section{DISCUSSION}

\section{Potential bias in results}

While the trip length of tracked birds was within the range of non-tracked birds, we did find a significant difference that suggested a potential bias in the habitat use and behavior of equipped birds. However, no physiological stress was observed while handling the birds and nest monitoring showed that the effect of tags on foraging activity did not affect breeding success.

Each bird contributed a different proportion of data to the kernel density analysis, which may have biased the kernel density analysis toward habitats visited by birds making longer foraging trips.

\section{Scale-dependent habitat selection}

During the 2003 chick-brooding period, waved albatrosses in this study mainly occupied oceanic waters within $100 \mathrm{~km}$ of their breeding site on Isla Española. This foraging range is significantly contracted compared to that of the incubation and chick-rearing periods, when breeding adults travel to and from the Peruvian upwelling and nearby waters. Our findings corroborate results from a previous study (Anderson et al. 2003) showing a short-term reduction in foraging range associated with hatchling nutritional needs. Within this limited foraging range, waved albatrosses used habitat non-randomly at several spatial scales. With respect to water column depth, brood-stage adults visited waters over the shallow Galápagos Platform and not nearby deep waters or steep slopes (Fig. 3, Table 1). Within the visited area over the platform, birds exhibited behavior consistent with foraging (low speed, high turn angle) over shallower waters than would be expected from random habitat selection (Table 2). At the finest scale, limited to bathymetric variation under the paths actually taken by the birds, behavior consistent with foraging and floating (resting) generally occurred over shallower water than did travelling behavior (Table 3). SST and chlorophyll concentration partly explained habitat-use, but were less consistent than was bathymetry in terms of frequency of statistical significance, proportion of variance explained, and relationship with habitat use (positive or negative). Nonetheless, these variables tended to indicate an orientation to cooler, more productive waters. These results provide strong support for part of our hypo- 
Table 4. Phoebastria irrorata. Comparison (mean $\pm \mathrm{SD}$ ) of behavior during foraging trips of males $(\mathrm{n}=13)$ and females $(\mathrm{n}=$ 13); for non-normal data, range is substituted for SD. Mean speed was calculated as total distance of straight lines between GPS locations divided by total duration of trip in hours, including each behavior, and therefore underestimates actual flight speed

\begin{tabular}{|c|c|c|}
\hline Parameter & Males & Females \\
\hline \multicolumn{3}{|l|}{ General trip characteristics } \\
\hline Total distance $(\mathrm{km})$ & $308.7 \pm 164.7$ & $289.8 \pm 134.9$ \\
\hline Total duration (h) & $122.2 \pm 70.1$ & $80.8 \pm 37.8$ \\
\hline Mean speed $\left(\mathrm{km} \mathrm{h}^{-1}\right)$ & $2.7 \pm 0.86$ & $3.9 \pm 1.7$ \\
\hline \multicolumn{3}{|l|}{ Activity during trip } \\
\hline Proportion spent floating & $0.45 \pm 0.09$ & $0.37 \pm 0.12$ \\
\hline Proportion spent traveling & $0.16 \pm 0.02$ & $0.25 \pm 0.03$ \\
\hline Proportion spent foraging & $0.39 \pm 0.09$ & $0.38 \pm 0.13$ \\
\hline \multicolumn{3}{|l|}{ Landings during trip } \\
\hline Total landings & $271.5(30-475)$ & $288.3(76-533)$ \\
\hline Landings $\mathrm{h}^{-1}$ & $2.8 \pm 1.5$ & $3.6 \pm 2.6$ \\
\hline Landings $\mathrm{km}^{-1}$ & $1.1 \pm 0.65$ & $1.1 \pm 0.68$ \\
\hline \multicolumn{3}{|l|}{ Body condition } \\
\hline Initial weight (g) & $4050.0 \pm 242.1$ & $3305.5 \pm 340.4$ \\
\hline Weight loss (g) & $479.2 \pm 363.4$ & $400.0 \pm 201.6$ \\
\hline$\%$ of weight lost & $0.115 \pm 0.089$ & $0.118 \pm 0.055$ \\
\hline
\end{tabular}

thesis that breeding waved albatrosses target shallow waters for foraging during all stages of the reproductive cycle, but provide only weak support for targeting of cool, productive waters. Ideally, a finer temporal scale for oceanographic data might represent habitat heterogeneity more accurately and reveal significant differences in foraging habitat; from the existing data, we used the most complete image available that incorporated the period of each trip.

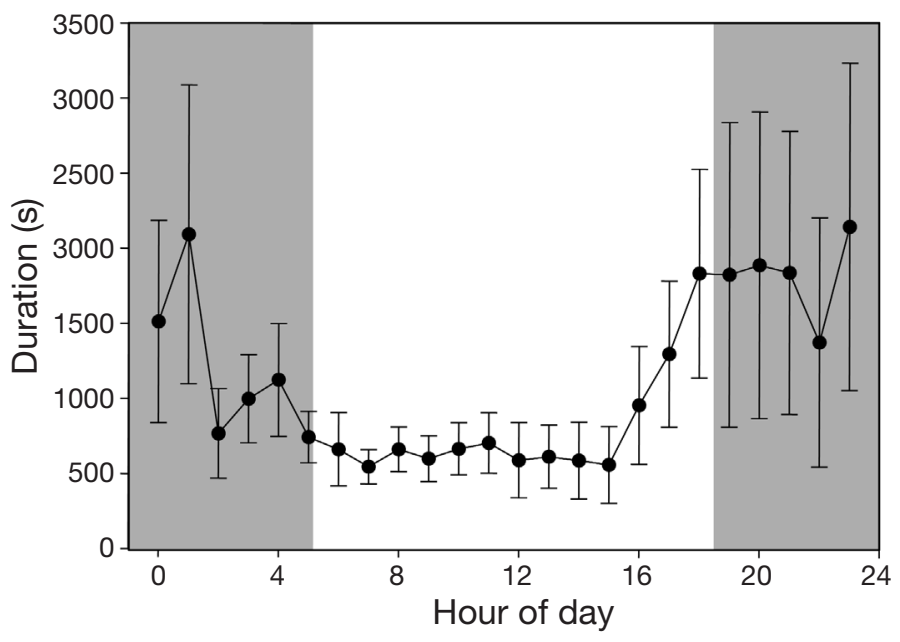

Fig. 6. Phoebastria irrorata. Mean ( $\pm 95 \%$ C.I.) duration of immersion as a function of hour of day in which perioid of immersion began. Shading: nighttime hours

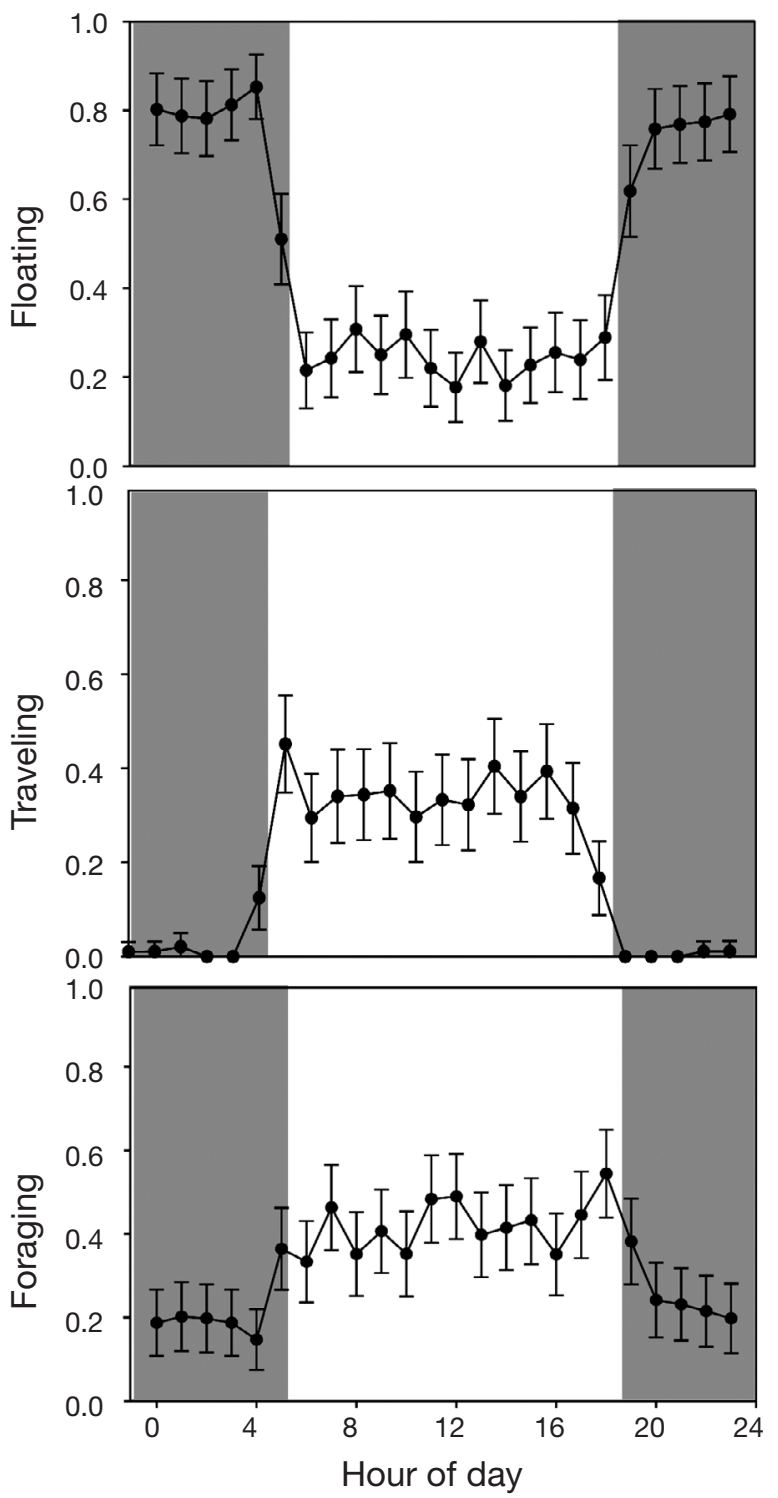

Fig. 7. Phoebastria irrorata. Proportion (mean $\pm 95 \%$ C.I.) of movement-defined behavior over the $24 \mathrm{~h}$ cycle. Shading: nighttime hours

While SST is strongly associated with seabird foraging and ultimately breeding success on a seasonal scale, waved albatrosses did not seem to actively discriminate SST heterogeneity on a much finer scale or concentrate their foraging efforts in cooler patches. The time when the parents are restricted to making short trips or alternating trip lengths is within the annual nadir of SST. Variability in SST within the archipelago is most influential on a seasonal scale, as anomalies associated with El Niño or La Niña affect waved albatross breeding-success (Harris 1973, Rechten 1985). Warmer SST in Antarctic waters also lowered reproductive success of albatrosses in the southern Indian Ocean (Inchausti et al. 2003). 


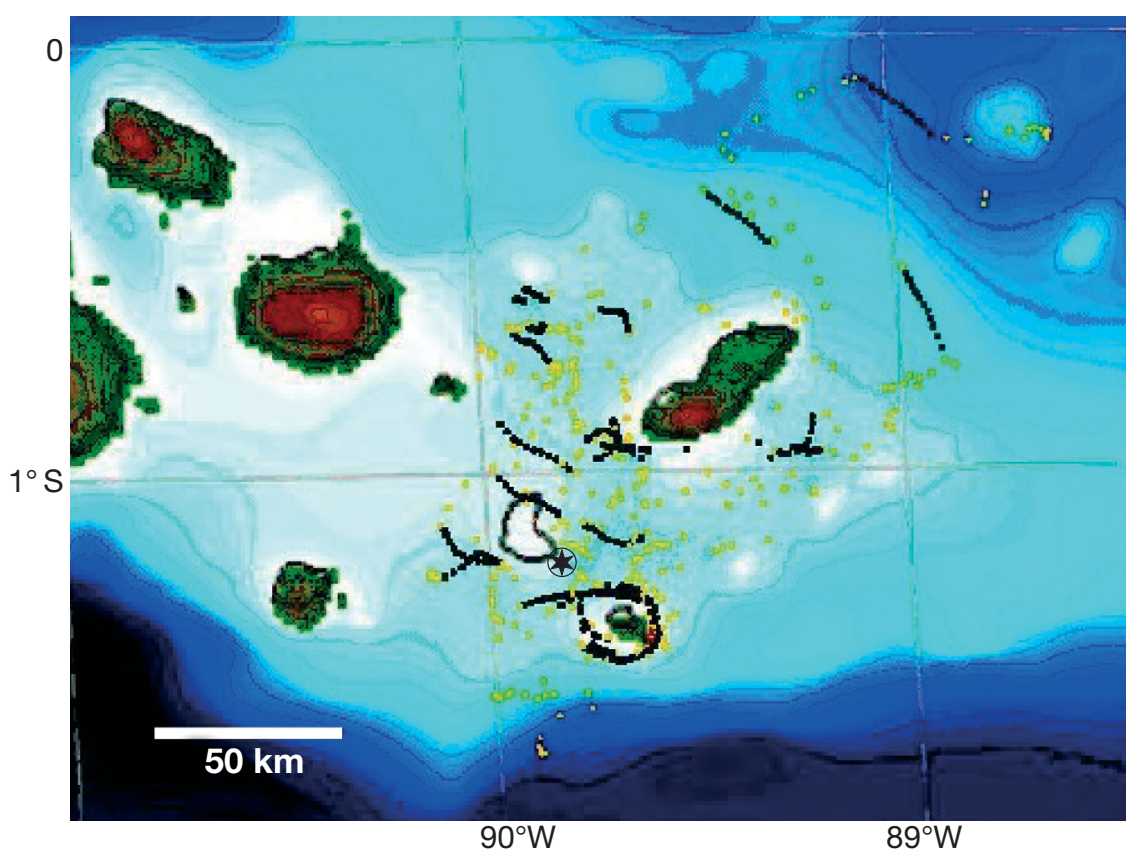

Fig. 8. Phoebastria irrorata. Diurnal (yellow) and nocturnal (black) GPS locations for 6 of the 26 trips

Brooding waved albatrosses occupied neritic, tropical, productive waters. Within the brooding foraging range, waved albatrosses were able to access waters that were shallower and more productive than habitat available to congeners, Laysan and black-footed albatrosses, within the restricted range closest to the breeding colony. Sea temperatures in the 2003 breeding season of the waved albatross were similar to SST in the 1998 breeding season of Laysan and blackfooted albatrosses (Hyrenbach et al. 2002). Like the subtropical Hawaiian species, waved albatrosses also encountered waters that were warmer and less productive than waters beyond the restricted foraging range. However, chlorophyll levels were generally higher in the foraging range of the brooding waved albatrosses than in areas where Laysan and blackfooted albatrosses foraged.

Heterogeneity in ocean depth caused by features such as seamounts allows eddies to bring prey items to the surface, and 2 high-density areas of foraging activity occurred to the SW and NE of the seamount known as Banco Ruso, NW of Isla Española. These may be areas where currents create such eddies, influenced by the NW flow of the Humboldt Current, as demonstrated by the direction in which albatrosses floated during the night. Seabird foraging activity is also concentrated over seamounts to the NE (Anderson \& Ricklefs 1987) and SW (G. Merlen pers. comm.) of Isla Española, further implicating bathymetry in the foraging distribution of Galápagos seabirds.

\section{Diurnal and nocturnal activity}

The patterns of diurnal flight and nocturnal floating observed in this study are common among albatrosses (Fernández \& Anderson 2000, Weimerskirch \& Guionnet 2002). While waved albatrosses were more active during the day, this activity may not indicate foraging exclusively, but rather a dual foraging strategy similar to that observed in large albatrosses at higher latitudes (Weimerskirch et al. 1997c). The combination of diurnal flight and foraging activity is indicative of successful patch localization, as demonstrated by increased frequency and decreased duration of ocean landings during the day in combination with a greater tendency to remain stationary during midday. GPS and immersion monitor data indicated that birds were floating or resting more during night hours, but some stationary activity at night suggests that birds might have been awaiting squid that float to the surface at night, and therefore remained in certain areas after having found concentrated prey. The positive correlation of nocturnal flight with increased moonlight suggests that birds may be more active during the full moon portion of the lunar cycle, contributing to the greater variance in duration of nocturnal immersions.

\section{CONCLUSION}

Foraging trips of brooding waved albatrosses occur mostly within a $100 \mathrm{~km}$ range of the breeding colony. Foraging and flight activity occur mainly during daylight hours, although an increase in nocturnal flight activity is correlated with greater amount of moonlight. Sex differences in foraging habitat are minimal during brooding. Bathymetry predicts habitat better than either SST or chlorophyll concentration within GMR, with scale-dependent variation in habitat use. The area surrounding the seamount Banco Ruso is a central feature in waved albatross habitat use during chickbrooding.

The rapid gain in submarine elevation west of Islas Isabela and Fernandina deflects the Cromwell Current, creating an upwelling with higher chlorophyll concentrations throughout the breeding season of the waved albatrosses. This highly productive area is beyond the maximum distance travelled by brooding waved albatrosses and is not used by them during this period; however, waved albatrosses are often observed 
in this area (Merlen 1996). During the early rearing period, chicks remain at the nest independently and parents resume their long trip foraging strategy to the continental shelf. Procellariiformes are known to alternate their foraging strategies between short trips which are more beneficial for the chick, and long trips which are more beneficial to the parent. When chicks are larger and can tolerate less-frequent meal delivery, parents may lengthen their shorter trips to access this area of the archipelago which at that time is cooler and much more productive than the rest of the archipelago. SST and chlorophyll may affect habitat selection more when parents are less constrained by the needs of the chick. Birds may also visit this area just prior to hatching, when foraging-trip length can vary.

Another possibility is that the waved albatrosses seen on the western side of the archipelago are nonbreeders. Time-budget data show that breeders and non-breeders have different time-use patterns which could imply differential foraging grounds that would reduce competition between breeders and non-breeders close to the breeding colony (Weimerskirch \& Wilson 2000). No tracking data exist for non-breeding waved albatrosses or adults from colonies on the other side of Española. Therefore, our knowledge of the use of the Galápagos Marine Reserve as foraging habitat of the entire waved albatross population remains incomplete.

Acknowledgements. We thank the Galápagos National Park Service for permission to work in the park, the Charles Darwin Research Station and TAME Airline for logistical support; the US National Science Foundation (award DEB 0235818 to D.J.A.) and the Wake Forest Environmental Studies department (Biodiversity in Latin America Grant) for research funding; M. McCaustland and E. Wakefield for field assistance; and the members of the Anderson laboratory group, G. Merlen, and 3 anonymous reviewers for comments on an earlier draft.

\section{LITERATURE CITED}

Anderson DJ (1989) Differential responses of boobies and other seabirds in the Galápagos to the 1986-87 El Niño-Southern Oscillation Event. Mar Ecol Prog Ser 52:209-216

Anderson DJ, Ricklefs RE (1987) Radio-tracking masked and blue-footed boobies in the Galápagos Islands. Natl Geogr Res 3:152-163

Anderson DJ, Schwandt AJ, Douglas HD (1998) Foraging ranges of waved albatrosses in the eastern Tropical Pacific Ocean. In: Robertson G, Gales R (eds) Albatross biology and conservation. Beatty \& Sons, Chipping Norton, p 180-185

Anderson DJ, Huyvaert KP, Apanius V, Anderson DJ and 10 others (2002) Population size and trends of the waved albatross Phoebastria irrorata. Mar Ornithol 30:63-39

Anderson DJ, Huyvaert KP, Wood DR, Gillikin CL, Frost BJ, Mouritsen H (2003) At-sea distribution of waved alba- trosses and the Galápagos Marine Reserve. Biol Conserv 110:367-373

Berrow SD, Croxall JP (2001) Provisioning rate and attendance patterns of wandering albatrosses at Bird Island, South Georgia. Condor 103:230-239

Brothers N (1991) Albatross mortality and associated bait loss in the Japanese longline fishery in the Southern Ocean. Biol Conserv 55:255-268

Croxall JP, Wood AG (2002) The importance of the Patagonian Shelf for top predator species breeding at South Georgia. Aquat Conserv: Mar Freshw Ecosyst 12:101-118

Croxall JP, Rothery P, Pickering SPC, Prince PA (1990) Reproductive performance, recruitment and survival of wandering albatrosses Diomedea exulans at Bird-Island, South Georgia. J Anim Ecol 59:775-796

Fernández P, Anderson DJ (2000) Nocturnal and diurnal foraging activity of Hawaiian albatrosses detected with a new immersion monitor. Condor 102:577-584

Fernández P, Anderson DJ, Sievert PR, Huyvaert K (2001) Foraging destinations of three low-latitude albatross (Phoebastria) species. J Zool 254:391-404

Fitzpatrick GL, Modlin MJ (1986) Direct line distances. Scarecrow Press, Metuchen, NJ

Fritz H, Said S, Weimerskirch H (2003) Scale-dependent hierarchical adjustments of movement patterns in a longrange foraging seabird. Proc R Soc Lond Ser B Biol Sci 270: $1143-1148$

Fukuda A, Miwa K, Hirano E, Suzuki M and 5 others (2004) BGDL-II - A GPS data logger for birds. Mem Natl Inst Polar Res Spec Iss 58:234-245

Grémillet D, Wilson RP, Wanless S, Chater T (2000) Blackbrowed albatrosses, international fisheries and the Patagonian Shelf. Mar Ecol Prog Ser 195:269-280

Grémillet D, Dell'Omo G, Ryan PG, Peters G, Ropert-Coudert Y, Weeks SJ (2004) Offshore diplomacy, or how seabirds mitigate inter-specific competition: a case study based on GPS tracking of Cape gannets from neighbouring colonies. Mar Ecol Prog Ser 268:265-279

Harris MP (1973) The biology of the waved albatross Diomedea irrorata of Hood Island, Galápagos. Ibis 115: 483-510

Harrison CS, Hida TS, Seki MP (1983) Hawaiian seabird feeding ecology. Wildl Monogr 85:1-71

Houvenaghel GT (1984) Oceanographic setting of the Galápagos Islands. In: Perry R (ed) Galápagos. Pergamon Press, Elmsford, p 43-54

Hyrenbach KD, Fernandez P, Anderson DJ (2002) Oceanographic habitats of two sympatric North Pacific albatrosses during the breeding season. Mar Ecol Prog Ser 233: 283-301

Inchausti P, Weimerskirch H (2001) Risks of decline and extinction of the endangered Amsterdam albatross and the projected impact of long-line fisheries. Biol Conserv 100:377-386

Inchausti P, Weimerskirch H (2002) Dispersal and metapopulation dynamics of an oceanic seabird, the wandering albatross, and its consequences for its response to longline fisheries. J Anim Ecol 71:765-770

Inchausti P, Guinet C, Koudil M, Durbec JP, Barbraud C, Weimerskirch H, Cherel Y, Jouventin P (2003) Interannual variability in the breeding performance of seabirds in relation to oceanographic anomalies that affect the Crozet and the Kerguelen sectors of the Southern Ocean. J Avian Biol 34:170-176

Jahncke J, Goya E, Guillen A (2001) Seabird by-catch in small-scale longline fisheries in northern Peru. Waterbirds 24:137-141 
Merlen GW (1996) Scavenging behavior of the waved albatross in Galápagos: a potential problem with increased longlining? Pac Seabirds 23:10-12

Nel DC, Lutjeharms JRE, Pakhomov EA, Ansorge IJ, Ryan PG, Klages NTW (2001) Exploitation of mesoscale oceanographic features by grey-headed albatross Thalassarche chrysostoma in the southern Indian Ocean. Mar Ecol Prog Ser 217:15-26

Prince PA, Croxall JP, Trathan PN, Wood AG (1998) The pelagic distribution of South Georgia albatrosses and their relationships with fisheries. In: Robertson G, Gales R (eds) Albatross biology and conservation. Beatty \& Sons, Chipping Norton, p 137-167

Rechten C (1985) The waved albatross in 1983 El Niño leads to complete failure. In: Robinson G, del Pino EM (eds) El Niño in the Galápagos Islands. Charles Darwin Foundation, Quito, p 227-237

Rodhouse PC, Prince PA, Trathan PN, Hatfield EMC, Watkins JL, Bone DG, Murphy EJ, White MG (1996) Cephalopods and mesoscale oceanography at the Antarctic Polar Front: satellite tracked predators locate pelagic trophic interactions. Mar Ecol Prog Ser 136:37-50

Schreiber RW, Schreiber EA (1984) Central Pacific seabirds and the El Niño Southern Oscillation: 1982 to 1983 perspectives. Science 225:713-716

Shaffer SA, Costa DP, Weimerskirch H (2003) Foraging effort in relation to the constraints of reproduction in freeranging albatrosses. Funct Ecol 17:66-74

Spear LB, Balance LT, Ainley DG (2001) Response of seabirds to thermal boundaries in the tropical Pacific: the thermocline versus the Equatorial Front. Mar Ecol Prog Ser 219: 275-289

Statsoft (1999) Statistica for Windows. Statsoft, Tulsa, OK

Waugh S, Troup C, Filippi D, Weimerskirch H (2002) Foraging

Editorial responsibility: Otto Kinne (Editor-in-Chief) Oldendorf/Luhe, Germany zones of Southern Royal Albatrosses. Condor 104:662-667 Weimerskirch H, Guionnet T (2002) Comparative activity pattern during foraging of four albatross species. Ibis 144:40-50

Weimerskirch H, Jouventin P (1987) Population dynamics of the wandering albatross, Diomedea exulans, of the Crozet Islands-causes and consequences of the population decline. Oikos 49:315-322

Weimerskirch H, Wilson RP (1992) When do wandering albatrosses Diomedea exulans forage? Mar Ecol Prog Ser 86:297-300

Weimerskirch H, Wilson RP (2000) Oceanic respite for wandering albatrosses: birds taking time off from breeding head for their favorite long-haul destinations. Nature 406:955-956

Weimerskirch H, Doncaster CP, Cuenot Chaillet F (1994) Pelagic seabirds and the marine environment: foraging patterns of wandering albatrosses in response to prey availability and distribution. Proc R Soc London Ser B Biol Sci 255:91-97

Weimerskirch H, Brothers N, Jouventin P (1997a) Population dynamics of wandering albatross Diomedea exulans and Amsterdam albatross $D$. amsterdamensis in the Indian Ocean and their relationships with long-line fisheries: conservation implications. Biol Conserv 79:257-270

Weimerskirch H, Wilson RP, Lys P (1997c) Activity pattern of foraging in the wandering albatross: a marine predator with two modes of prey searching. Mar Ecol Prog Ser 151:245-254

Weimerskirch H, Bonadonna F, Bailleul F, Mabille G, Dell'Omo G, Lipp HP (2002) GPS tracking of foraging albatrosses. Science 295:1259-1259

Zar JH (1996) Biostatistical analysis, 3rd edn. Prentice-Hall, Upper Saddle River, NJ

Submitted: June 17, 2004; Accepted: October 21, 2004

Proofs received from author(s): March 29, 2005 